\title{
THE EFFECTIVENESS OF FLASHCARDS IN TEACHING VOCABULARY FOR SEVENTH GRADE STUDENTS OF SMP WAHIDIYAH KEDIRI
}

\author{
Lathifah Nur Ma'rifah', Imam Suhaimi² \\ Wahidiyah University of Kediri ${ }^{1}$, University of Kahuripan Kediri ${ }^{2}$ \\ $\underline{\text { latifaaja346@gmail.com }{ }^{1} \text {, Suhaimi yes@kahuripan.ac.id }{ }^{2}}$
}

\begin{abstract}
This research is generally to find out the differences in the English vocabulary ability between students are taught by using Flashcards and those are not taught by using Flashcards for seventh grade students of SMP Wahidiyah Kediri. The research applied in Experiment Class and Control Class. The instruments for collecting the data were interview, field note, Pre-test and Post-test. The researcher uses Quasi-experiment and uses quantitative method with analyzed the data by using T-test. The result shows that there is significance different between students are taught by using Flashcards and those are taught by using TPS (Think Pair Share). The data analysis shows that Tcount $>T_{\text {table }}$ $(4,330>1,664), \mathrm{Ha}$ is accepted. In Pre-test, the average score of Experiment Class is 62, 44 and Control Class is 72, 79. In Post-test, the average score of Experiment Class is 83, 49 and Control Class is 69. The result shows that the average score of Experiment Class is higher than Control Class in Post-test.
\end{abstract}

Keywords: Vocabulary, Teaching Vocabulary, Flashcards.

\section{INTRODUCTION}

In our country many students lack of vocabulary, they get difficulties to understand and communicate in English that is caused vocabulary limitation and the use of media in learning is less interesting. Komachali and Khodareza (2012) state that "Vocabulary is an intrinsic part of language teaching". So, vocabulary is an essential component in language learning, because without vocabulary nothing can be conveyed.

According to Harmer (2001) some aspects that have to be discuss in vocabulary, namely word meaning, how words extend their use, how words combine and the grammar of words". Therefore, vocabulary is one of the most important part of language to be able understand in communication, because someone who understand in communication must be learn about the vocabulary and expression.

The kind of vocabulary according to Harmer (2001) distinguish two types of vocabulary, namely Active and Passive vocabulary. Active vocabulary that the students have been taught or learnt and they are expected to be able use it in own speaking and writing. Passive vocabulary is the word which the students will recognize but they will probably not be able to produce it in listening or reading material. 
In other hand, the researcher finds any problem in teaching English vocabulary knowledge that in lack in speaking and writing. The researcher have to choose the suitable words and media that an appropriate the students need, because the students are different level and ability in vocabulary mastery. The researcher uses traditional method with visual technique. It can help the beginner to understand and memorize the new vocabulary. The researcher will try to give them a media that can be learners memorize a new vocabulary quickly and easily, namely Flashcards.

Scrivener (2005) state that "Flashcards is ELT jargon for pictures that you can show the students, typically something you can hold up when standing in front of the whole class". It can also use to practice words. So, Flashcards are the cards which contain word and picture that help the students to memorize the new vocabulary easily.

The advantage of Flashcards in teaching vocabulary according to Cross (1992) "Flashcards in teaching vocabulary can strengthen form and meaning in the students' memory. It helps to make teaching and learning less boring and make students attention in the classroom activity.

The researcher chooses seventh grade of SMP Wahidiyah Kediri in becomes the object of the research. It is caused SMP Wahidiyah Kediri is a school base on Islamic boarding school. Before do the research, the researcher observes background of the students, how to teacher teaches English especially in vocabulary and the extant of students' interest in teaching English. The researcher also interview with English teacher of SMP Wahidiyah and one of the seventh grade students in SMP Wahidiyah Kediri. Then, the researcher finds that students of SMP Wahidiyah Kediri come from different backgrounds, region, cultures and ethnic. They live in the Islamic boarding school environment that has variation language. It is undeniable that mother tongue is the first language that are mastery. Indonesian language is a second language as a tool communication with other friends from different region. So that, not all the students master in foreign language like as English. Introduce a foreign language is not easy like as introducing the first and the second languages that are used in daily. Acquiring English vocabulary to the students are first step to make them interest.

\section{METHOD}

The research on effect of Flashcards in teaching vocabulary for seventh grade of SMP Wahidiyah Kediri is quasiexperimental. A quasi-experimental study is a type of evaluation which aims to determine a program or intervention the effect on a study's participants. Pre and Posttest design, a treatment group and control group of study participant, quasiexperimental studies lack one or more of these design elements.

In this study, there are independent variable and dependent variable. The independent variable is the method of using 
Flashcards and text book, the dependent variable is the seventh grade's vocabulary of SMP Wahidiyah Kediri.

The researcher gives them a Pre-test to Control and Experiment class. Then, the researcher gives them treatment in 4 meetings. The last, researcher takes Post-test to the students. The purpose to know how about the result of students' vocabulary mastery after getting treatment.

The researcher used cluster sample. "Cluster Sampling (Sampel kelompok) is a technique for taking sample based on predetermined group of member of the population" (Arikunto, 2013).

The sample used in this research is two classes of seventh grade of SMP Wahidiyah Kediri. The researcher chooses classes that have the same ability based on the results of interviews with English teacher of seventh grade in SMP Wahidiyah, so class VIIC and class VIID have the same level ability.

The researcher gave Pre-test in two classes. Then, the researcher got the result of the Pre-test. They were assigned into Experiment and Control class. The class that has a lower average value would be an Experimental class. The researcher have given them a treatment namely Flashcards method. Another class would be a Control class. The researcher given them a traditional method namely TPS (Think Pair Share).

Instrument of this research is vocabulary test. The researcher gives multiple choice questions test Pre and Post- test. Each of Pre and Post-test consists of 20 multiple choice questions. The researcher also interviewed English teacher and one of the seventh grade students of SMP Wahidiyah Kediri. Then, the researcher observe the English teacher teaches in the class.

"A good instrument there are two important requirements namely valid and reliable" (Arikunto, 2013). The researcher uses content validity and reliability using Microsoft Excel formulation. The questions valid, if R-value > R-table. The formulation to account the reliable of instrument. Before gives treatment, the researcher arrange the questions that valid and reliable. The questions about noun, verb and adverb. The number of question and material that related with vocabulary in Pre and Post-test.

The researcher have tested 20 questions for 35 students in class VIIA SMP Wahidiyah Kediri. The data would be valid and reliable if it was R-value > R-table. In rtable, the validity from 35 students or respondent is 0,32 . $\mathrm{N}(\mathrm{Df})$ is $33(\mathrm{Df}=\mathrm{N}-2=$ $35-2=34$ ) and the significant is 0,05 . If $\mathrm{R}-$ value is less than 0,32 , the question is invalid. In R-table, the reliability from 20 question with 35 respondent is 0,42 . The researcher found the value of index reliable is 0,66 . So, R-value $>$ R-table $(0,66>0,42)$ the question is reliable.

The researcher analyzes the data using T-test formulation. The T-test formulation was finding significant between Pre and Post-test. There are any different significant students' vocabulary mastery 
who are taught by using Flashcards and those who are not taught by using Flashcards in seventh grade students of SMP Wahidiyah Kediri. Before analyze the data, the researcher measured normality and homogeneity of the data by using IBM SPSS v.18.

Statistical hypothesis as follow: Tvalue < T-table, Ho is accepted and $\mathrm{Ha}$ is rejected. T-value $>$ T-table, Ha accepted and Ho is rejected. Null Hypothesis (Ho). There is no significant difference between students' vocabulary achievement with Flashcards and without Flashcards or used TPS (Think Pair Share).

\section{RESEARCH FINDING}

This study was conducted to find out whether the differences between the students who are taught using Flashcards and without using Flashcards. This study used quasi experimental designed which consists of two subject, Experiment and Control Class. From such class in seventh grade of SMP Wahidiyah, the researcher got class VIIC and VIID. That is way, the researcher chosen that class. VIIC class consists of 43 students and VIID class consists 36 students. The researcher was selected VIIC as the Experiment Class and VIID as the Control Class. It was determined based on the result of the average value of the Pre-test.

The data was collected from the students' Pre and Post test score and observed guide with interviewed an English teacher and seventh grade students then observed an English teacher taught in class.

The researcher interviewed to the English teacher and one of the seventh grade students in SMP Wahidiyah Kediri. Then, the researcher had observed how an English teacher taught in VIIC and VIID of SMP Wahidiyah. The researcher used field note to observe. After that, the Pre-test was conducted first to the Experiment and Control Class. The result of the Pre-test provides information about both of class' ability in vocabulary. The result of the test about the students' achievement before treatment. The number of questions of the test were 20 questions for 75 students, 41 students from class VIIC and 34 students from class VIID.

The Pre-test was done before treatment. This test was given to know competence and knowledge of all students. The mean of Pre-test for class VIIC is 62, 44 and class VIID is 72,79 . So, class VIIC was Experiment Class and VIID was Control Class.

After getting the result of Pre-test, the researcher gave the treatment to all students. The treatment was taught by using Flashcards to the Experiment Class and by using traditional method, namely TPS (Think Pair Share) to the Control Class. The activities during treatment of Experiment Class namely Flashcards.

The last, Post-test was administered then to both of class after the Experiment Class got the treatments and the Control Class taught through traditional method. 
The mean of Post-test for class VIIC is 83, 49 from 43 students and class VIID is 69 from 36 students. The result of the test showed that the students' vocabulary mastery who have been taught by using Flashcard have higher ability than the students who have not been taught by using Flashcards in seventh grade students of SMP Wahidiyah Kediri.

There is a good progress of students' vocabulary. In Pre-test, the average of students' score is 62, 44 while in Post-test, the average of students' score is 83,49 . So, the average gain of the students' total score is 21,05 .

The following table described above, the researcher presents the frequency distribution score from the result of the students' Pre-test in Experiment Class, and the researcher presents it in table 1.

Table 1, Frequency Distribution of Pre-test Score in Experiment Class

\begin{tabular}{|c|c|c|c|c|}
\hline Valid & $\begin{array}{c}\text { Frequenc } \\
y\end{array}$ & Percen & $\begin{array}{c}\text { Valid } \\
\text { Perce } \\
\text { nt }\end{array}$ & $\begin{array}{l}\text { Fumulativ } \\
\text { e Percent }\end{array}$ \\
\hline 50 & 7 & 17.1 & 17.1 & 17.1 \\
\hline 55 & 6 & 14.6 & 14.6 & 31.7 \\
\hline 60 & 7 & 17.1 & 17.1 & 48.8 \\
\hline 65 & 8 & 19.5 & 19.5 & 68.3 \\
\hline 70 & 7 & 17.1 & 17.1 & 85.4 \\
\hline 75 & 6 & 14.6 & 14.6 & 100.0 \\
\hline Total & 41 & 100.0 & 100.0 & \\
\hline
\end{tabular}

After the researcher gave the treatment using Flashcards for the Experiment Class, the researcher gave Post- test to them. The data of Post-test score showed in table 2 .

Table 2. Frequency Distribution of Post-test Score in Experiment Class

\begin{tabular}{|c|c|c|c|c|}
\hline Valid & $\begin{array}{c}\text { Frequen } \\
\text { cy }\end{array}$ & Percent & $\begin{array}{c}\text { Valid } \\
\text { Percent }\end{array}$ & $\begin{array}{c}\text { Cumulat } \\
\text { ive } \\
\text { Percent }\end{array}$ \\
\hline 60 & 2 & 4.9 & 4.9 & 4.9 \\
65 & 2 & 4.9 & 4.9 & 9.8 \\
70 & 4 & 9.8 & 9.8 & 19.5 \\
75 & 3 & 7.3 & 7.3 & 26.8 \\
80 & 6 & 14.6 & 14.6 & 41.5 \\
85 & 8 & 19.5 & 19.5 & 61.0 \\
90 & 6 & 14.6 & 14.6 & 75.6 \\
95 & 4 & 9.8 & 9.8 & 85.4 \\
100 & 7 & 14.6 & 14.6 & 100.0 \\
Total & 42 & 100.0 & 100.0 & \\
\hline
\end{tabular}

After conducting Pre-test, conventional teaching and Post-test to the Control Class. The average of students' Posttest score compared with the average of students' Pre-test score is decrease. In Pretest, the average of students' score is 72, 79 while in Post-test, the average of students' score is 69 . So, the average gain of the students' total score is $-3,79$.

The following table described the frequency distribution score from the result of the students' Pre and Post-test in Control Class, the researcher presents it in table 3. 
Table 3. Frequency Distribution of PreTest Score in Control Class

\begin{tabular}{|c|c|c|c|c|}
\hline Valid & $\begin{array}{c}\text { Frequen } \\
\text { cy }\end{array}$ & Percent & $\begin{array}{c}\text { Valid } \\
\text { Percent }\end{array}$ & $\begin{array}{c}\text { Cumulat } \\
\text { ive } \\
\text { Percent }\end{array}$ \\
\hline 45 & 1 & 2.9 & 2.9 & 2.9 \\
50 & 1 & 2.9 & 2.9 & 5.9 \\
55 & 5 & 14.7 & 14.7 & 20.6 \\
60 & 2 & 5.9 & 5.9 & 26.5 \\
65 & 2 & 5.9 & 5.9 & 32.4 \\
70 & 4 & 11.8 & 11.8 & 44.1 \\
75 & 7 & 20.6 & 20.6 & 64.7 \\
80 & 4 & 11.8 & 11.8 & 76.5 \\
85 & 1 & 2.9 & 2.9 & 79.4 \\
90 & 4 & 11.8 & 11.8 & 91.2 \\
95 & 3 & 8.8 & 8.8 & 100.0 \\
Total & 34 & 100.0 & 100.0 & \\
\hline
\end{tabular}

After the researcher gave the treatment without Flashcards, but used TPS (Think Pair Share) for the Control Class, the researcher gave Post-test to them. The data of Post-test score showed in table 4.

Table 4. Frequency Distribution of Post-test Score in Control Class

\begin{tabular}{|c|c|c|c|c|}
\hline Valid & $\begin{array}{c}\text { Freque } \\
\text { ncy }\end{array}$ & Percent & $\begin{array}{c}\text { Valid } \\
\text { Percent }\end{array}$ & $\begin{array}{c}\text { Cumulati } \\
\text { ve Percent }\end{array}$ \\
\hline 45 & 2 & 5.9 & 5.9 & 5.9 \\
50 & 6 & 17.6 & 17.6 & 23.5 \\
55 & 3 & 5.9 & 5.9 & 29.4 \\
60 & 5 & 11.8 & 11.8 & 41.2 \\
65 & 3 & 8.8 & 8.8 & 50.0 \\
\hline 75 & 3 & 8.8 & 8.8 & 58.8 \\
80 & 6 & 17.6 & 17.6 & 76.5 \\
85 & 2 & 5.9 & 5.9 & 82.4 \\
\hline
\end{tabular}

\begin{tabular}{r|c|c|c|c|}
\hline 90 & 4 & 11.8 & 11.8 & 94.1 \\
100 & 2 & 5.9 & 5.9 & 100.0 \\
Total & 36 & 100.0 & 100.0 & \\
\hline
\end{tabular}

Experiment Class from 62, 44 to be 83,49 but in Control Class there is decrease average, from 72,79 to be 69 . So, it shows that the students who have been taught by using Flashcards have higher than those who have been taught by using TPS (Think Pair Share).

The researcher analyzed the data by using normality test, homogeneity test and hypothesis test.

The normality test in this research used Kolomogorov-Smirnov method in IBM SPSS v.18 with criteria significance $>0,05$. The researcher presents of the data in table 5.

\begin{tabular}{|c|c|c|c|c|c|c|}
\hline \multirow{1}{*}{} & \multicolumn{2}{|c|}{$\begin{array}{c}\text { Kolmogorov- } \\
\text { Smirnov }\end{array}$} & \multicolumn{3}{c|}{ Shapiro-Wilk } \\
\cline { 2 - 7 } & $\begin{array}{c}\text { Statist } \\
\text { ic }\end{array}$ & Df & Sig. & ic & Df & Sig. \\
\hline PRE7C & .132 & 41 & .071 & .914 & 41 & .004 \\
POST7C & .128 & 43 & .090 & .946 & 43 & .050 \\
\hline
\end{tabular}

a. Lilliefors Significance Correction

Table 5. Normality Test of Pre-test and

Post-test in Experiment Class

From the table above, it can be seen that the significance of Pre-test and Post-test score in Experiment Class is 0,071 in Pre-test and 0,090 in Post-test.

There is the result of normality test in Pre and Post class VIID or Control Class. The researcher presents of the data in table 6. 
Table 6. Test of Normality of Pre-test and Post-test in Control Class

\begin{tabular}{|c|c|c|c|c|c|c|}
\hline & \multicolumn{2}{|c|}{$\begin{array}{c}\text { Kolmogorov- } \\
\text { Smirnov }\end{array}$} & \multicolumn{3}{c|}{ Shapiro-Wilk } \\
\cline { 2 - 7 } & $\begin{array}{c}\text { Statist } \\
\text { ic }\end{array}$ & Df & Sig. & ic & Df & Sig. \\
\hline PRE7D & .122 & 34 & .200 & .953 & 34 & .154 \\
POST7D & .144 & 36 & .071 & .930 & 36 & .030 \\
\hline
\end{tabular}

a. Lilliefors Significance Correction

There was decrease from Pre-test to Post-test in Kolmogorov-Smirnov statistic. The significance of Pre-test score in Control Class is 0, 200 and 0, 071 in Post-test.

But, the data were also normally distribute because the significant result is higher than 0,05 . It mean that the data of Pre and Posttest in Experiment and Control Class are normally distributed.

The homogeneity test was done using IBM SPSS v.18 for windows with criteria $p>$ 0,05 . The researcher used Levene Statistic. The data are presented as follows in table 7.

Table 7. Homogeneity Test of Experiment and Control Class

\begin{tabular}{|c|c|c|c|c|}
\hline & $\begin{array}{c}\text { Levene } \\
\text { Statistic }\end{array}$ & df1 & df2 & Sig. \\
\hline 7C (EC) & 2.621 & 1 & 84 & .109 \\
\hline 7D (CC) & 3.429 & 1 & 70 & .069 \\
\hline
\end{tabular}

Based on Table 7, it can be seen that the statistic of Levene, Experiment Class is lower than Control Class. The significance of Experiment Class is higher than Control Class. It can be concluded that the significance is higher than 0,05 . So, Experiment Class and Control Class are homogeneous. This research used IBM SPSS v.18 to analyze the data. The researcher compared between students' Pre-test score Post-test score in table 8.

Table 8. Group Statistic between Post and Pre-Test in Experiment Class

\begin{tabular}{|c|c|c|c|c|}
\hline & & & $\begin{array}{c}\text { Std. } \\
\text { Deviatio } \\
\mathrm{n}\end{array}$ & $\begin{array}{c}\text { Std. } \\
\text { Error } \\
\text { Mean }\end{array}$ \\
\hline $\begin{array}{c}\text { POST7 } \\
\text { C }\end{array}$ & 83.78 & 43 & 11.444 & 1.787 \\
PRE7C & 62.44 & 41 & 8.450 & 1.320 \\
\hline
\end{tabular}

There is a change in the average value of students before and after being given treatment.

\begin{tabular}{|c|c|c|c|c|}
\hline & Mean & $\mathrm{N}$ & $\begin{array}{c}\text { Std. } \\
\text { Deviatio } \\
\mathrm{n}\end{array}$ & $\begin{array}{c}\text { Std. } \\
\text { Error } \\
\text { Mean }\end{array}$ \\
\hline $\begin{array}{c}\text { POST7 } \\
\text { D }\end{array}$ & 69.7059 & 36 & 16.60327 & 2.84744 \\
PRE7D & 72.7941 & 34 & 13.93661 & 2.39011 \\
\hline
\end{tabular}

Table 9. Group Statistic between Post and Pre Test in Control Class

The table showed that it is a decrease value before being treatment and after being treatment. So, the treatment provided is not right for the Control Class.

In this research, the researcher used two variable, namely dependent and independent variable. The learning model, the researcher used Flashcards for Experiment Class and TPS (Think Pair Share) for Control Class. The purpose of that model to the effectiveness of the Flashcards learning for seventh grade students. The 
result of that learning, the researcher presents in table 10.

Table 10. T-test Independent

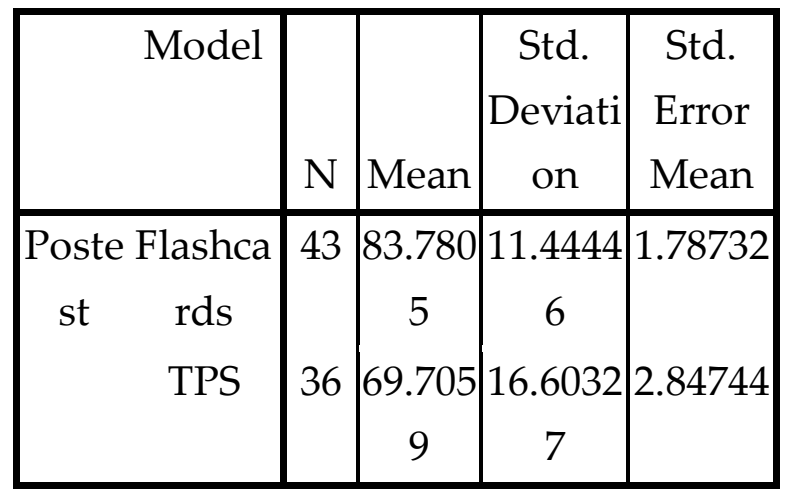

The table above showed that the average value of Flashcards is higher than TPS (Think Pair Share). So, Flashcards is better than TPS. Flashcards learning is effective for seventh grade students in SMP Wahidiyah. The learning model could be improve the students' ability to memorize.

For the criteria of hypothesis test are if $\mathrm{t}$-value < $\mathrm{t}$-table, Ho (Null Hypothesis) is accepted and Ha (Alternative Hypothesis) is rejected. Ho (Null Hypothesis) was accepted "there was no significant effect in teaching vocabulary between seventh grade students of SMP Wahidiyah who are taught by using Flashcards and TPS (Think Pair Share)". If Tvalue > T-table, Ho (Null Hypothesis) is rejected and Ha (Alternative Hypothesis) is accepted. Ha (Alternative Hypothesis) was accepted, "there was a significant effect in teaching vocabulary between seventh grade students of SMP Wahidiyah who are taught by using Flashcards and TPS (Think Pair Share)".

Table 11. T-test Result

\begin{tabular}{|c|c|c|}
\hline Indep & Leve & \\
ende & ne's & \\
nt & Test & t-test for Equality of Means \\
\hline
\end{tabular}

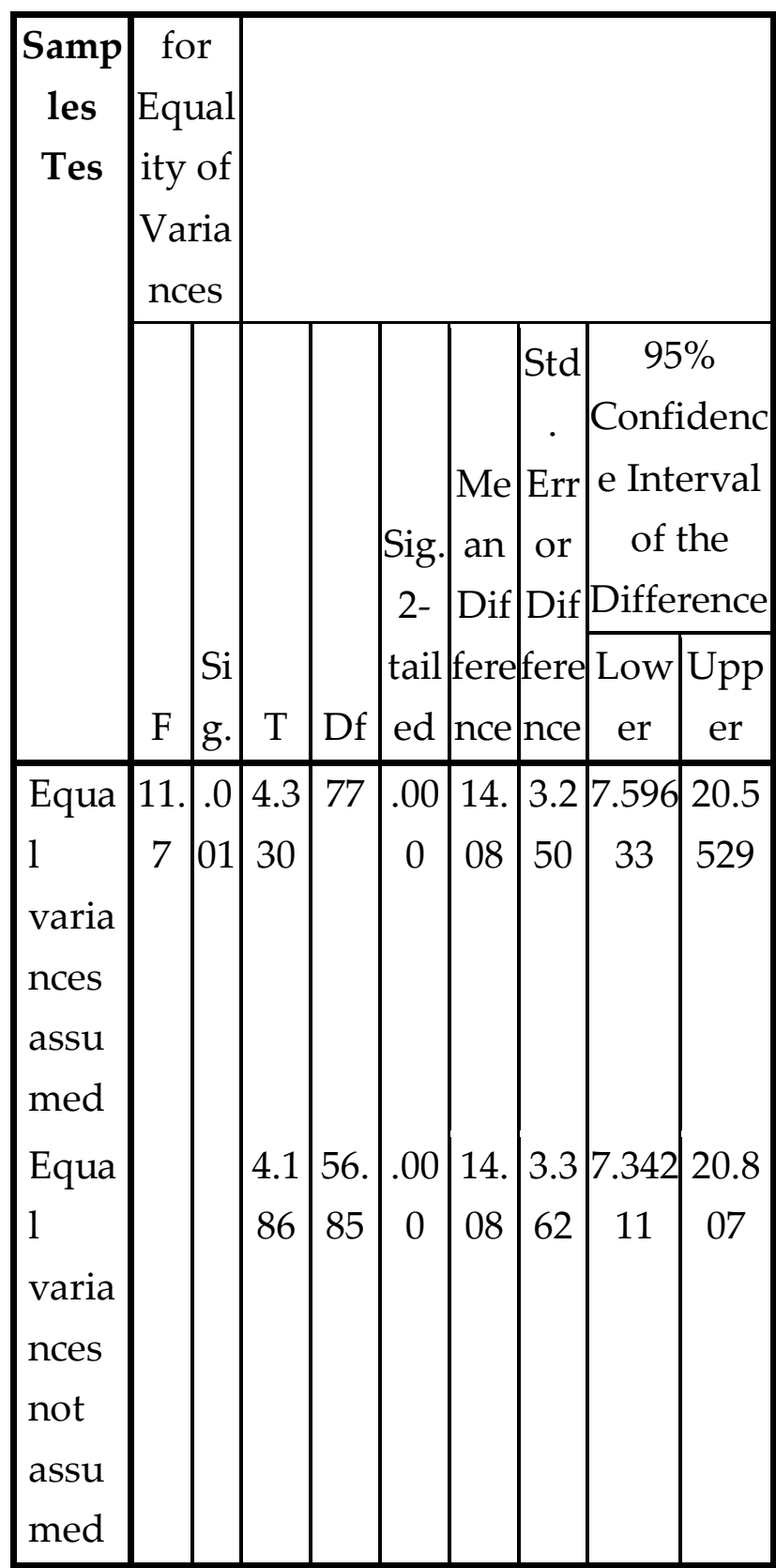

In table 11 above, the result of T-test, $\mathrm{T}$-value is 4,330 . The table showed the degree of freedom (Df) was 77 (the students of Experiment Class + the students of Control Class $-2=36+43-2=77$ ). The value of T-table is 1, 664 with Df 77 in significant level $5 \%(0,05)$. It concluded that T-value > T-table, $(4,330>1,664)$.

The calculation of the table 11 that the null hypothesis (Ho) was rejected and alternative hypothesis (Ha) was accepted. There was significant difference between the 
two classes (2-tailed), the students' vocabulary achievement by using Flashcards and without Flashcards or used TPS (Think Pair Share).

\section{DISCUSSION}

SMP Wahidiyah Kediri is school based on Islamic Boarding School that the students of SMP Wahidiyah Kediri have differences background, characteristic and ability, especially in learning English. In Elementary School, the students are only taught English at a glance not profound. So, not all the students mastering in foreign language like as English. Acquiring English vocabulary with interesting technique and media are the first step to make them more enthusiastic.

The result of this research was proved by the students' involvement in the teaching and learning process such as giving appropriate responds to the researcher's instructions. It is in line with the theory proposed by Nation (2001) that word cards are beneficial for vocabulary learning with Alqahtani (2015) stated that find out the appropriate techniques which implemented to the students and suitable material in order to gain the target language. So, some techniques can use to help their students practice vocabulary more interest.

The picture are one of the solutions that can help the teacher to explain using illustration of person or thing. It means that the media of communication to get clearer ideas or information. Smaldino (2005) states that pictures are photographic (representation of people or things in the form of two dimensional of sequential pictures).

After knowing the result applying Flashcards, the researcher collaboration with English teacher to treat the students by applying Flashcards in teaching learning process. The researcher takes solution of the students' problem according to Cross (1991) that Flashcards are effective that can be used for any level students and for practicing structure word in variety games. It can amuse and help to make teaching vocabulary less boring.

Flashcards have various benefits and aspect of foreign language. Pictures can motivate students in learning vocabulary process, make the material clearer and help students to understand the material, especially in interesting way for junior high school.

In conducting the Experiment Class they were given vocabulary Pre-test and Post-test to find out the students' vocabulary before and after the treatment. The result is the students who taught by Flashcards is higher than students taught without Flashcards or teaching used TPS (Think Pair Share). TPS is a good method but it is not suitable for students of Junior High School in SMP Wahidiyah Kediri which requires students to be more active. So that some students in Control Class get a decrease in score from Pre-test to Post-test. Flashcards are better appropriate to students' needs and curriculum are applied. 


\section{CONCLUSION}

Based on the research conducted on seventh grade of SMP Wahidiyah Kediri in academic year 2018/2019, it could be concluded that there was effect of using Flashcards in teaching vocabulary. The result of students' vocabulary mastery could be seen from Pre-test and Post-test from each class. The researcher used T-test to test the hypothesis and know the significant difference of the Experiment and Control class. The students' vocabulary mastery whom were taught by using Flashcards was higher than students' vocabulary mastery whom are taught without Flashcards, especially at seventh grade students of SMP Wahidiyah Kediri. So, teaching English on vocabulary mastery by using Flashcards is effective.

\section{SUGGESTION}

There were some suggestions for English teachers, the students and other researchers. English teachers should be more creative in teaching and learning process in order to increase students' interest in learning English. Teachers could use various teaching techniques and teaching media, Flashcards for instance which are interesting, enjoyable and meaningful by considering various aspects. It can help the students easier in memorizing and mastering vocabulary.

For the students should be more active or have high motivation in teaching and learning process because they have important roles in achieving their success in learning.

For other researchers, this media offers a good way in teaching English vocabulary especially for seventh grade, because it helps the students to memorize and remember easily.

\section{BIBLIOGRAPHY}

Arikunto, Suharsimi. (2013). Prosedur Penelitian: Suatu Pendekatan Praktik. Jakarta: Rineka cipta.

Brown, H.D. (2000). Teaching by Principles: An Interactive Approach toLanguage Pedagogy. Second edition. San Francisco, California: Longman.

Cameron, Lynne. (2001). Teaching Languages to Young Learners. New York: Cambridge University Press.

Campillo, R.M.L. (1995). Teaching and Learning Vocabulary: An Introduction for English Students. https://dialnet.uniroja.es/descarga/ar ticulo/2282507.pdf. (accessed on February 28, 2019. at 9.30p.m.)

Cross, David. (1992). A Practical Handbook of Language Teaching. UK: Prentice Hall International.

Gelfgren, Veronica. (2012). Fun with Flashcards. Swedish: Learn more projects.

Harmer, Jeremy. (2001). The Practice of English Language Teaching. Third edition. New York: Longman.

Komachali, E.M., \& Khodareza, Mohammadreza. (2012). The Effect of Using Vocabulary Flash Card on 
Iranian Pre-University Students'

Vocabulary Knowledge. Vol. 5, No. 3.

pp. 134-147. Iran: International

Education Studies.

Mayristanti. (2016). The Effect of Using

Flashcards on Students' Vocabulary

Achievement (A Quasi-experimental

Study at The Seventh Grade Students

of SMPN 178 Jakarta). Jakarta: UIN

Syarif Hidayatullah.

Nation, I.S.P. (2001). Learning Vocabulary in

Another Language. Wellington:

Victoria University.

Nation, I.S.P. (2007). Learning Vocabulary in

Another Language. Australian

Review of Applied Linguistics, Vol.

30, No. 1, pp. 10.1-10.3. Monash University Epress.

Safirah, Zeni. (2016). Improving Vocabulary

Mastery through Vocabulary Cards

of Grade VII Students at SMP

Institute Indonesia Yogyakarta in the 2015/2016 Academic Year. Yogyakarta: UNY.

Scrivener, Jim. (2005). Learning Teaching: A Guidebook for English Language Teachers. Second Edition. Macmillan Publishers Limited.

Smaldino, S.E. et.al. (2005). Instructional Technology and Media for Learning. Eight edition. Ohio: Pearson.

Thornbury, Scott. (2002). How to Teach Vocabulary. England: Longman. 